\title{
THE IMPACT OF SELF-ESTEEM AND INTERNET USE ON ACADEMIC PERFORMANCE
}

\author{
Edhi Juwono ${ }^{1}$ and I. Hardhy Winarta ${ }^{2}$
}

\author{
${ }^{1,2}$ Faculty of Economics and Business, ABFI Institute of Perbanas \\ Jln. Perbanas, Karet Kuningan, Setiabudi, Jakarta Selatan, DKI Jakarta, 12940, Indonesia \\ 'edhi.juwono@perbanas.id; ${ }^{2}$ hardhy.winarta@perbanas.id
}

Received: $1^{\text {st }}$ August 2016/ Revised: $15^{\text {th }}$ November 2016/ Accepted: $6^{\text {th }}$ December 2016

\begin{abstract}
The students' academic performance is one of important evaluation factors in accreditation. It is interesting to explore the factors which give impact to the academic achievement or performance. This research put academic performance as the research problem. Since this research was combining two disciplines: information systems (IS) and educational management (EM), it set Internet Use (representing IS) and self-esteem (representing EM) as factors impacting the academic performance. Moreover, this research used the quantitative method. Based on the quantitative research model, the research used primary data collected from students of ABFI Institute of Perbanas, Jakarta. The data was calculated using a statistical tool called SPSS. The descriptive statistics was also applied to describe the variables, and regression technique was for describing the relationship between the variables. After analyzing the data, the research finds that self-esteem affects the academic performance significantly and positively, but the Internet use does not impact the academic performance significantly.
\end{abstract}

Keywords: academic performance, self-esteem, Internet use

\section{INTRODUCTION}

The final achievement of learning activities is the academic performance of students. In terms of managerial and applicable factors, it becomes one of the assessment criteria in the accreditation process is the average Grade Point Average (GPA) during the last five years (Badan Akreditasi Nasional Perguruan Tinggi, 2008). From the scientific side, the current performance problems or academic achievement (academic performance) is still an interesting study interest of researchers (Marcela, 2015; Omar, Mohammed, \& Paimin, 2015; Al-Qahtani, 2015; Abdi, Yasavoli, \& Yasavoli, 2015). Therefore, this research tries to raise the academic performance issue.

Academic achievement or performance is defined as "The individual mastery and proficiency in a particular field "(Aziz \& Ahmad, 2008). Some researches especially those that take the object of research in universities use the Grade Point Average (GPA). Moreover in Malaysia, it is known as Purata Nilai Gred Kumulatif (PNGK) or Cumulative Grade Point Average (CGPA) to describe achievement or academic performance (McKenzie \& Schweitzer 2001; Hunley et al., 2005; Rivkin et al., 2005; Aziz \& Ahmad, 2008; Chen \& Fu, 2009; Kirschner \& Karpinski, 2010; Hamjah, 2012; Goreyshi et al., 2013; Usman, Alavi \& Shafeq, 2014; Marcela, 2015; Omar, Mohammed, \& Paimin, 2015; AlQahtani, 2015; Abdi, Yasavoli, \& Yasavoli, 2015). In this research, academic performance is defined as the mastery and proficiency of students in the academic field.

As for measuring the students' academic performance, it uses GPA of the odd semester 2015/2016. For this research, academic achievement are grouped into five levels, namely (1) 0,01 to 1,50 ; (2) 1,51 to 1,99 ; (3) 2,00 to 2,49 ; (4) 2,50 to 2,99 ; and (5) 3,00 to 4,00 .

Self-esteem is considered as one of the instructions that ensure the success of one's life and psychological health (Goreyshi et al., 2013). Moreover, they also define self-esteem as self-acceptance, self-appreciation, and selfrespect. Self-esteem is affected by the goal or purpose of one's life (Pepi, Faria, \& Alesi, 2006). Furthermore, Vialle, Heaven, and Ciarrochi (2005) added that they tend not to distinguish between the self-esteem and the self-concept. It means the self-esteem is closely related to how one appreciates and respects himself/herself. In this research, self-esteem is defined as "The way of a student in appreciating and respecting himself/herself". The determination indicators for measuring self-esteem follows the Rosenberg Self-Esteem Scale (Crowe, 2002).

In this research, Internet use refers to the use of the Internet as a network of computing and telecommunication which builds societies known as cyber community or virtual community (Hunley et al., 2005). They indicate that the Internet use includes the pattern of computers usage because the use of the Internet must be through the computational media. There is interesting data to be noted, in the United States, since 1989 secondary school students have already used computer although it seemed that they have not used the Internet. It is because at the moment the Internet has not been released to the public. In that year there were $39 \%$ of high school students used computers at school, and $20 \%$ of students even used computers in their homes (Hunley et al., 2005). However, it does not mean that the use of computers and the Internet are only monopolized by the superpower country. Data on Internet use in Indonesia is also amazing. In 1995, it was estimated that Internet users in Indonesia had reached 10,000 users as mentioned pintarkomputer.org (2015). However, in 2014, the Internet users has reached 88.1 million users (Puskamom UI and APJII, 2015).

The definition of Internet use in this research follows the theory from Chen and Fu (2009). They defined Internet use as "The learning media in the $21^{\text {st }}$ century providing many opportunities that cannot be utilized by students before this century". In this research, the concept of Internet use is defined as "Internet use by students to improve their academic performance or achievement". The measuring instruments or indicators used follows Chen and Fu (2009).

The research is carried out without any pretension to find all of the solutions related to the achievement/ academic performance. By limiting the scope in the Faculty of Economics and Business (FEB) Asian Banking Finance 
and Informatics Institute (ABFII) in Perbanas Jakarta, the solutions proffered as the factors which are considered influential to the problem, are self-esteem and use of the Internet. The problem-solution model is formulated into a conceptual model or conceptual framework (frame of thought), which later becomes the basis of the research model. In building the conceptual model, it needs the support from the previous researches. The research contains a relationship between academic performance/academic achievement and self-esteem are found in the research conducted by Vialle, Heaven, and Ciarrochi (2005) and Martin et al. (2005). While the research containing the findings of how the academic performance/achievement is related to the use of the Internet can be found on the research by Jackson et al. (2006), and Chen and Fu (2009).

The description in the background provides the basis to formulate the research questions. The issue or the problem examined is the student's academic performance at FEB ABFII Perbanas. The proposed solutions are selfesteem and use of the Internet. The relationship between the problems and the solutions are made into the following research purposes that are to analyze: (1) the condition of self-esteem, Internet use, and the academic performance; (2) the impact of self-esteem of students on their academic performance; (3) the impact of Internet use of students on their academic performance.

\section{METHODS}

One of the researches that discussed achievements/ academic performance was conducted by Vialle, Heaven, and Ciarrochi (2005). Their research involved 900 students of grade 7 through 12 in the Catholic Diocese Wollongong, Australia. They found that there was no significant correlation between self-respect and academic achievement. Jenaabadi (2014) conducted the research on 300 students (S-1 and S-2) in Kahnooj University of Payam-e Nour, Iran which reinforced Vialle, Heaven, and Ciarrochi (2005). He found that there was no significant relationship between self-esteem and academic achievement. In addition, Pepi, Faria, and Alesi (2006) conducted a research empirically involving 1.540 middle school students of the final level and students at the beginning of the Italian and Portuguese in their respective countries. They found that there was no correlation between self-esteem and academic performance in Italian pupils and students. However, for the pupils and students of Portuguese, there was a positive correlation between self-esteem and academic achievement. Since there was an inconsistency between the finding of Pepi, Faria, and Alesi (2006) especially the researches on the Portuguese students and two other types of research, there is still research gap for conducting research, which puts the relationship between self-esteem and academic performance.

Chen and $\mathrm{Fu}$ (2009) conducted research on the middle school students in northern Taiwan (Taipei City, Taipei County, and Yi-Lan County). They were involving 2.690 students with the ages ranging from 13-15 years. The results showed that the patterns of Internet use had a significant effect on students' academic achievement. They also found that the search for information on the Internet improved the academic performance. The use of the Internet for games and use the Internet in cafe resulted in bad achievement in passing the exam. The research conducted by Kirschner \& Karpinski (2010) on 102 undergraduate and graduate students of Midwestern State University in the United States found that the Facebook (FB) users had a lower GPA and spent fewer hours for study compared to non-FB users. Both types of research indicate that there is a significant relationship between Internet use and the achievement/academic performance. The relationship can be either positive or negative depends on the usage patterns.

On the other side, Usman, Alavi, and Shafeq (2014) found a contrast result comparing to the researches of Pepi, Faria and Alesi (2006), and Chen and Fu (2009). Their research involved 120 students spread across four countries (China, Yemen, Somalia and Indonesia). Usman, Alavi, and Shafeq (2014) found that there was no significant relationship between Internet addiction which was another term for Internet use and the academic performance. This research is contrary to the other two researched conducted by Pepi, Faria, and Alesi (2006), and Chen and Fu (2009). Therefore, it is still relevant to conduct research to ascertain the relationship between academic performance and use of the Internet.

The research model that will be used is shown in Figure 1.

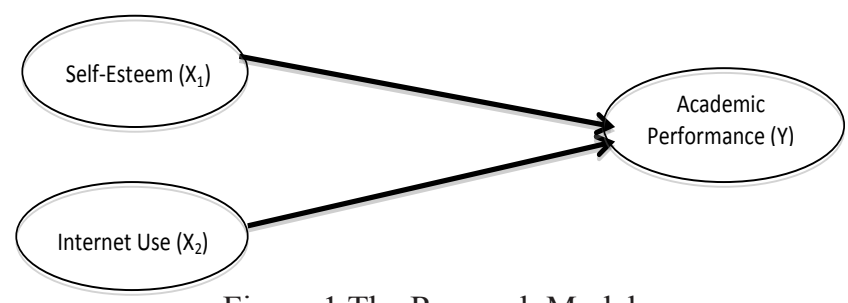

Figure 1 The Research Model

The population of this research is the students of the Faculty of Economics and Business (FEB) IKPIA Perbanas in the even semester of the 2015/2016 academic year. Based on data from Academic Administration Section of FEB IKPIA Perbanas, the number of registered students in the second semester of academic year 2015/2016 is 2.825 students.

The Slovin formula was applied to determine the sample. It can be seen below.

$n=\frac{2.825}{\left(1+2.825(0,05)^{2}\right)}=350,387$

Where the descriptions are:

$\begin{array}{ll}\mathrm{n} & =\text { sample size } \\ \text { Population } & =2,825 \\ \text { Standard error } & =0,05\end{array}$

There are five hundred questionnaires distributed. Around 411 questionnaires are filled in, and the eligible ones are 395 questionnaires.

Based on the purpose of the research, there are two kinds of analysis used. The descriptive analysis is applied to answer the first research purpose. Then, the causal analysis is applied for the second and third purpose. Last, the statistical tools of SPSS are used to calculate the data as a basis for descriptive analysis and causal analysis.

\section{RESULTS AND DISCUSSIONS}

Based on the statistical calculation, there are two findings. The first one is a descriptive finding based on the 
fifteen questions in the questionnaires, and the second one is the implicational finding based on the hypotheses testing. The data taken for the variable of self-esteem $\left(\mathrm{X}_{1}\right)$ is the data collected by the ten questions in the questionnaire. The tenth question was compiled by adopting the Rosenberg Self-Esteem Scale (Crowe, 2002). The answers to the ten questions are outlined as following.

First, the statistical calculation results on the statement "I feel I am a person of worth at least on an equal basis with others " show different opinion. From the majority Student of FEB IKPIA Perbanas, $61,5 \%$ of them feel that they do not have an equal basis with others. Only $12,6 \%$ agree with the statement. The rest around $25,8 \%$ are in the position of in between.

Second, for the statement, "I feel that I have a number of good qualities", it describes more than half of students $(55,1 \%)$ feel having a number of good qualities. It means that the majority who feels worthy is at least on an equal basis with others by considering themselves as a person who has some good qualities. In other words, most of them who are not willing to be compared with others at the same level have a positive attitude. They felt that they are not the same with others because of their advantages. Only a small number of them $(4,9 \%)$ fell having no advantages.

Third, on the statement, "All in all, I am inclined to feel that I am a failure", it shows that most of them $(53,7 \%)$ do not agree with the statement. This majority opinion is aligned with the majority opinion of the second question.

Fourth, the statistical calculation on the statement, "I am able to do things as well as most other people" illustrates that most of them $(70,3 \%)$ agree with the statement. It means they consider themselves as good as the others.

Fifth, in the statement, "I feel I do not have much to be proud of", it states that most of them $(61 \%)$ do not agree with the statement. It confirms their opinion on the second question that they have advantages.

Sixth, the analysis result of the statement, "I take a positive attitude toward myself" shows us that majority of respondents $(80,5 \%)$ agree with the statement. It means they appreciate themselves, and it is in line with their opinion on the second statement.

Seventh, result in the statement, "On the whole, I am satisfied with myself." describes that the majority of the students $(49,4 \%)$ are satisfied with themselves. While $36,2 \%$ of them are in between agree and not agree. Only $14,4 \%$ students disagree with the statement. It means they are not satisfied with themselves. However, if it is compared with the next statement (the eighth statement), it can be considered what they have meant with "are not satisfied" is in a positive way. They feel that they still have to have more respect to themselves.

Eighth, the analysis result of the statement, "I wish I could have more respect for myself" states that most of them $(71,4 \%)$ agree with the statement. It means they are not satisfied with themselves and are going to have more respect to themselves.
Ninth, in the statement, "I certainly feel useless at times", it shows that most of them $(65,6 \%)$ disagree with the statement. Only $29,4 \%$ of students feel useless, while $5,1 \%$ are in between. This can mean that most of them have felt that they are worth enough.

Tenth, the result of the statement, "At times I think I am no good at all." states that majority of the respondent $(54,4 \%)$ disagree with the statement. The result supports the previous statement.

Moreover, the data obtained for the variable of Internet use $\left(\mathrm{X}_{2}\right)$ is the data collected by the questions in the questionnaire. There are four questions. The answers are outlined as following. First, the analysis result of the statement, "Frequency of using the Internet" illustrates that most of them $(91,4)$ use the Internet every day. Then 5,1\% of respondents use Internet 1-3 times a week, and 1,8\% of them use it once a week. The rest uses the Internet less than once a week. Second, the analysis result of the statement, "I am using the Internet for gathering information" shows that most of them $(93,4 \%)$ use the Internet for information gathering. Third, for the statement, "I am using the Internet for chatting with friends, families, or relatives" shows around $92,6 \%$ of students use the Internet to chat. Fourth, in the statement, "I am using the Internet for playing games", it describes that some of them $(36,2 \%)$ use the Internet to play games. $29,8 \%$ of them do not use the Internet to play games, and $33,9 \%$ are in between.

The last one is data for variable academic performance $(\mathrm{Y})$. The data is collected from a question in the questionnaire. The statement, "My grade point average (GPA) until the odd semester of 2015/2016 academic year", has the answer that most of them $(56,7 \%)$ have GPA of 3,00 $-4,00$. While, $34,2 \%$ of them had GPA of 2,50-2,99.

Based on the descriptive analysis, it is concluded that most of the student of Faculty of Economics and Business ABFI Institute of Perbanas Jakarta are having self-esteem. Most of them use the Internet to gather information and chat. Most of the respondents $(90,9 \%)$ have GPA above 2,49 . Furthermore, it can be described that the implicational analysis is for testing hypotheses about the effects of selfesteem variable $\left(\mathrm{X}_{1}\right)$ and Internet Use $\left(\mathrm{X}_{2}\right)$ on academic performance (Y). The result can be seen in Table 1.

Based on Table 1, it can be seen that with $t_{\text {value }}$ of 3,965 with 0,000 significance value is $<0,05$, the hypothesis which states, "the self-esteem of FEB IKPIA Perbanas Students impacts the academic performance" is accepted. Furthermore, with $t_{\text {value }}$ of 1,046 with 0,296 significance value is $<0,05$, the hypothesis which is "the Internet use of FEB IKPIA Perbanas Students impacts the academic performance" is not accepted. Therefore, this strengthens the research results of Pepi, Faria, and Alesi (2006) in particular for their research on students and Portuguese: self-esteem is positively correlated with achievement or academic performance. On the other hand, the results are not in line with the findings of several researchers. There are Vialle, Heaven, and Ciarrochi (2005), Pepi, Faria, and

Tabel 1 Partial Regression

\begin{tabular}{rlccccc}
\hline \multirow{2}{*}{ Model } & \multicolumn{2}{c}{ Unstandardized Coefficients } & Standardized Coefficients & \multirow{2}{*}{ t } & \multirow{2}{*}{ Sig. } \\
\cline { 2 - 5 } & \multicolumn{1}{c}{ B } & Std. Error & Beta & & 9,006 & 0,000 \\
& (Constant) & 3,305 & 0,367 & & 3,965 & 0,000 \\
& Self-esteem & 0,026 & 0,006 & 0,197 & 1,046 & 0,296 \\
\hline
\end{tabular}

Dependent Variable: Academic Performance 
Alesi (2006) in their research on the Italian students, and Jenaabadi (2014) who found that self-esteem did not have a significant impact on academic performance. Furthermore, this research supports the results of Kirschner and Karpinski (2010), and Usman, Alavi, and Shafeq (2014), who stated that the use of the Internet did not relate to academic performance. However, this research does not support the results of Chen and Fu (2009) who stated that Internet use significantly had an impact on academic performance.

\section{CONCLUSIONS}

There are two conclusions in this research. First, the results indicate that the self-esteem has an impact on academic performance. The majority of respondents (more than $50 \%$ ) have good self-esteem, and over $50 \%$ of the respondents have a good academic performance (marked with IP above 3,00). Second, it indicates that the use of the Internet has no effect on academic performance. The majority of respondents (over 90\%) use the Internet every day, but less than $60 \%$ of the respondents have a good academic performance (above 3,00).

The finding describes there is a significant impact of self-esteem on academic performance which can be implied for human resources management. It can be conducted as the future research by exploring whether it will support the claim of Baumeister et.al. (2003) that there are weak and positive correlations between job performance and selfesteem or not.

The finding that states that there is no relationship between Internet use and academic performance is a little bit surprising. It is because the Internet can be considered as a part of daily life, especially in this research more than $90 \%$ of respondents use the Internet every day. This can be conducted as a further research specifying the use of the I nternet as the knowledge gathering and fulfilling the assignments.

\section{REFERENCES}

Abdi, M., Yasavoli, H. M., \& Yasavoli, M. M. (2015). Assessment of structural model to explain life satisfaction and academic achievement based on parenting styles. Procedia-Social and Behavioral Sciences, 182, 668-672. http://doi.org/10.1016/j. sbspro.2015.04.806

Al-Qahtani, M. F. (2015). Associations between approaches to study, the learning environment, and academic achievement. Journal of Taibah University Medical Sciences, 10(1), 56-65. http://doi.org/10.1016/j. jtumed.2015.01.014

Aziz, M. N. A. \& Ahmad, N. S. (2008). Kemahiran belajar dan hubungannya dengan pencapaian akademik: (The relationship between learning skills and students academic achievement: A study in the district of Kerian, Perak). Pendidik dan Pendidikan, 23, 29-47.

Badan Akreditasi Nasional Perguruan Tinggi. (2008). Buku $V$ pedoman penilaian akreditasi program studi sarjana. Jakarta: Badan Akreditasi Nasional Perguruan Tinggi.

Baumeister, R. F., Campbell, J. D., Krueger, J. I., \& Vohs, K. D. (2003). Does high self-esteem cause better performance, interpersonal success, happiness, or healthier lifestyles?. Psychological science in the public interest, 4(1), 1-44.

Chen, S., \& Fu, Y. (2009). Internet use and academic achievement: gender differences in early adolescence. Adolescence, 44(176), 797-812.

Crowe, T. V. (2002). Translation of the Rosenberg Selfesteem Scale into American sign language: A principal components analysis. Social Work Research, 26(1), 57-63.

Goreyshi, M. K., Kargar, F. R., Noohi, S., \& Ajilchi, B. (2013). Effect of combined mastery-cooperative learning on emotional intelligence, self-esteem and academic achievement in grade skipping. ProcediaSocial and Behavioral Sciences, 84, 470-474. http:// doi.org/10.1016/j.sbspro.2013.06.586

Hamjah, S. H., Rozali, E. A., Rasit, R. M., \& Ismail, Z. (2012). The relationship between spiritual practice and student's academic performance. Universiti Kebangsaan Malaysia, Malaysia, 4(2), 51-60.

Hunley, S. A., Evans, J. H., Delgado-Hachey, M., Krise, J., Rich, T., \& Schell, C. (2005). Adolescent computer use and academic achievement. Adolescence, 40(158), 307-318.

Jackson, L. A., Von Eye, A., Biocca, F. A., Barbatsis, G., Zhao, Y., \& Fitzgerald, H. E. (2006). Does home Internet use influence the academic performance of low-income children? Developmental Psychology, 42(3), 429-35. http://doi.org/10.1037/00121649.42.3.429

Jenaabadi, H. (2014). Studying the relation between emotional intelligence and self esteem with academic achievement. Procedia - Social and Behavioral Sciences, 114(2004), 203-206. http://doi. org/10.1016/j.sbspro.2013.12.685

Kirschner, P. A., \& Karpinski, A. C. (2010). Facebook ${ }^{\circledR}$ and academic performance. Computers in Human Behavior, 26(6), 1237-1245. http://doi.org/10.1016/j. chb.2010.03.024

Marcela, V. (2015). Learning Strategy, personality traits and academic achievement of university students. Procedia-Social and Behavioral Sciences, 174, 34733478. http://doi.org/10.1016/j.sbspro.2015.01.1021

Martin, G., Richardson, A. S., Bergen, H. A., Roeger, L., \& Allison, S. (2005). Perceived academic performance, self-esteem and locus of control as indicators of need for assessment of adolescent suicide risk: implications for teachers. Journal of Adolescence, 28(1), 75-87. http://doi.org/10.1016/j. adolescence.2004.04.005

McKenzie, K., \& Schweitzer, R. (2001). Who succeeds at university? Factors predicting academic performance in first year Australian university students. Higher Education Research \& Development, 20(1), 21-33. http://doi.org/10.1080/07924360120043621

Omar, N., Mohamad, M. M., \& Paimin, A. N. (2015). Dimension of learning styles and students' academic achievement. Procedia-Social and Behavioral Sciences, 204 (November 2014), 172-182. http://doi. org/10.1016/j.sbspro.2015.08.130

Pintarkomputer.Org.(2015). Pengertian dan sejarah Internet 
di Indonesia dan dunia. Retrieved on November $26^{\text {th }}$, 2014 from http://www.pintarkomputer.org/2015/04/ pengertian-dan-sejarah-Internet-di.html

Pepi, A., Faria, L., \& Alesi, M. (2006). Personal conceptions of intelligence, self-esteem, and school achievement in Italian and Portuguese students. Adolescence, 41(164), 615-631.

Puskamom UI dan APJII. (2015). Profil pengguna Internet 2014. Jakarta: Asosiasi Penyelenggaran Jasa Internet Indonesia.

Rivkin, S. G., Hanushek, E. A., Kain, J. F., \& Kain, J. E. (2005). Teachers, schools, and academic achievement. Econometrica Econometrica, 73(2), 417-458.

Usman, N. H., Alavi, M., \& Shafeq, S. M. (2014). Relationship between Internetaddiction and academic performance among foreign undergraduate students. Procedia-Social and Behavioral Sciences, 114, 845851. http://doi.org/10.1016/j.sbspro.2013.12.795

Vialle, W., Heaven, Patrick, C. L., \& Ciarrochi, J. (2005). The relationship between self-esteem and academic achievement in high ability students: Evidence from the Wollongong Youth Study. The Australian Journal of Gifted Education, 14(2), 39-45. 